\title{
Assessment of agricultural information needs and search behaviour of farmers in Andhra Pradesh state
}

\author{
J. Phani Vardhan* and Y. Prabhavathi \\ Institute of Agribusiness Management, Acharya N.G. Ranga Agricultural University, Guntur (A.P.) India \\ (Email:jpvardhan.3@gmail.com)
}

\begin{abstract}
Farmers need information at all stages of crop production to post-harvest management. To assess the agricultural information needs and search behaviours of farmers study was under taken in two districts viz., Krishna and Guntur districts of Andhra Pradesh state on selected 100 progressive farmers. From the obtained data farmers were divided into three search behaviours and the significance with socio-economic characteristics and information needs were assessed using chi square and Kruskal Wallis test and found literacy status, land holding, usage of mobile phone and technical information, price or market related information were shown significance. Then logit regression was done to identify the type of impact the variables showing on search behaviours and found that secondary education, mobile phone usage and cultivation practices were shown significance impact in negative way.
\end{abstract}

Key Words : Agriculture, Information, Search behaviours

View Point Article : Vardhan, J. Phani and Prabhavathi, Y. (2020). Assessment of agricultural information needs and search behaviour of farmers in Andhra Pradesh state. Internat. J. agric. Sci., 16 (2) : 197-202, DOI:10.15740/HAS/IJAS/16.2/197-202. Copyright@ 2020: Hind Agri-Horticultural Society.

Article History : Received : 08.03.2020; Revised : 07.05.2020; Accepted : 13.05.2020

\footnotetext{
* Author for correspondence:
} 